\title{
SOCIAL BARRIERS TO FEMALE EDUCATION IN DISTRICT D.G KHAN
}

\author{
Basharat Ali \\ Lecturer, Department of Sociology, \\ Government College University Faisalabad \\ basharat492@gmail.com \\ Shahid Nadeem \\ Research Scholar, Department of Sociology, \\ Government College, University Faisalabad \\ Hammad Shafqat \\ Research Scholar, Department of Sociology, \\ Government College, University Faisalabad
}

\begin{abstract}
Education plays a significant role in community development. Women represent half of the population of a country when half population remains illiterate than it is difficult to achieve the goals of development. Poor policies low budget for education and low implantation of educational programs create illiteracy gap among masses. The present study is designed to investigate the barriers that female are facing in the field of education. The study was conducted in the Tribal Area of district Dera Ghazi Khan. The simple random simple techniques were used, and data were collected through questionnaire. The aim of this study is to identify the factors that are the hurdle for female education. The scattered population and school distance create a serious issue for education. The study revealed that higher the distance from the school the lower will be enrollment. Low income of parents will also affect the enrollment of children. The study reveals that lack of transports; school distance, school expenses, household work, traditional customs and financial issues are the barriers for female education.
\end{abstract}

Key words: Attitude, Females, education, Income, Customs, Barriers.

\section{INTRODUCTION}

Education is a method of learning through which men understand his relationship with its environment. Education helps to progress to groom personality in a positive direction. Female education plays a significant role in the development of a country. Those countries which neglect girl's child educations are disgustingly unbalanced and poor. Lack of female's education not only effect on the family but also impact on the whole community and country (Mercy, 2017).

Education is a crucial milestone to change human behavior, it is not just to take a degree, but it opens a narrow mind and enlarges human thinking. The studies illustrate that the majority of illiterate people are in underdeveloped countries. The prosperous of a country depends upon the education of the public. Low literacy rate increase poverty in a country. Females' literacy rate remains low in Pakistan due to poor situation of facilities, gender discrimination and low income. Cultural factors are strong barriers to female education. The government must take initiative to solve these problems in rural areas of Pakistan by building schools and encourage people through the educational programs (Shurgeel et al, 2015).

Physical infrastructure e.g. lack of schools, colleges, teacher and transportation is an obstacle for girls education. The findings show that many girls are not going to school due to these factors because schools are located away from home there are no facilities of transportation so parents fear to send their daughter away from school. This problem is a dilemma for women education as our society is also suffering from different problems like terrorism and religious extremism and no security is available for protection. Therefore, parents do not agree to send their girls into schools (Sheikh et al, 2013). 
In Pakistan usually public consider that sons are helping hands of a family and prefer their sons. They think that women are unable to earn and believe women are weak and incapable to perform their duties like a man. The study of District Faisalabad village Dasuha revealed gender discrimination against female. The birth of a female considers humiliation but the birth of boys considers the blessing of God. They think that it is the responsibility of sister and mother to serve their brothers, husband and father. Serving of women to men is considering congenital (Mohyuddin \& Ambreen, 2013).

History demonstrates that male attitude towards female is dominant and female consider weak sex from old age till present. In 2011 from "Puducherry" no women took any ticket for assembly this show that women are marginal. Such type of problem can only be solved through education and empowerment. First, we should empower illiterate women so that they express their skills and then educate women to play their role (Shantilin, 2011).

Females are always busy in household work she is serving the whole family her every day start with work and end with work. In rural areas, they also work in farming. The male gets up and goes for work. The parents always prefer their boys and girls are always negligible. Therefore, most of the time of girls waste in household work and she have no time to attend school, consequently, she always dropout from school (Mohyuddin \& Ambreen, 2012).

According to the international report, the education system in Pakistan is very low and it goes down due to poverty. The reason behind this issue is that the budget of education is very low, political unrest, corruption, weak supervision and syllabus. So people distrust on the government sector and believe in the private sector but the private sector is not approachable for poor people. Mostly private schools are in urban areas and the majority of populations are in rural areas. The gender gap, elite and poor gap is a major issue for development. Therefore, the literacy rate remains the lowest in Pakistan (Benz, 2012).

Coleman states, "The education system of a country is the master determinant of all aspects of change." But in Pakistan, the education budget from 2002 to 2003 is 1.8 per cent. This figure shows that politicians and the government of Pakistan are not interested in education but government stress on primary education. Only primary education cannot play their role for social change and sustainable development. The government and policy maker planned for the industrial sector as these industrial belong to themselves. Educations for girls were never primacy of government, five years plan for educations were totally failed government cannot achieve the educational goal. In urban areas of Pakistan the ratio of girl's boys in the primary, middle and higher level is equal but in rural areas, the ratio of girls is half than boys because the level of awareness is less and scarcity of resources is a major issue. (Mahmood, 2012).

Parents distress that if they send their girls in school they will lose interest in home managing and their marriage will also be late. In Nigeria the ratio of child marriage is high due to societal pressure their parents do not send him to school and marry their daughter soon. As a result, the ratio of childbearing is high among female. Male domination effect female education and most parents send their sons in school (Kaur \& Letic, 2012).

The rural women are uneducated it is due to their traditional thinking they thought that women are only labor of household. But other obstacles are not negligible like insufficient school and bad infrastructure. To create awareness in people we should work with rural people and aware them that educating women means to educate a family and educating man means to educate a person. It is the responsibility of the community to spread women education and appreciate female education. The community must inform the government about female socio-economic issues and other barriers (Asghar, 1992).

Socio-economic issues are an obstruction for women education. In developing countries, parents are poor their children are involved in child labor as a result mostly parents drop out their children from school. The parents are interested to teach their girls in higher education but they cannot afford their expenses, as a result, they excluded their girls from school. So poverty is the exclusion of education the researcher suggests that the government should take a serious interest in female education. National and international aid should be given to female students and the parents should be properly guided for the importance of education (Jacob, 2014). 


\section{REVIEW OF LITERATURE}

Education empowers women about their social, economic and political rights. It also helps them to improve their quality of life and to root out gender discrimination. An educated woman is a gift for family and she is aware of the domestic affairs. Educated women socialize their children in a positive way; educated mother has a strong effect on child education (Okorie, 2013).

Tissington \& Misty (2011) identified that poverty effects child education as poor people cannot afford the basic need of life. Poverty creates an academic and achievement gap as for poor students achievement gap is always at risk. Students always affected by the values of the community. Poor family and communities cannot understand the value and importance of education. In schools, there is a great difference between rich and poor people. Poor students consider themselves inferior to other students. These gaps compel students to leave education as a result of child age they start working. So poverty effect academic achievement teachers should make a relationship with students and encourage them.

Farrulsaqlain examined that national policies play a crucial role in girls' education. Poor management policies are an impediment for girl's education in Pakistan. The other issues that the researcher identified are cultural issues, political environment, equality of education and access to schools are major obstacles in Pakistan.

Zahid et al. (1999) studied that poverty and gender influence in child education. The data were collected through a stratified sampling technique from household and community. The collection processes were further divided into poor and rich people. The researchers found that the way behaving of the poor is different from the rich. The poor people children dropout ratio was higher rich people. The findings show that poor people fewer attend school. The main reason behind this that income effect child education. In rural areas, the behavior of parents is bias they prefer their sons. The ratio of boys in school was more than girls.

Khan (2019) viewed that illiteracy is strongly related to poverty. In this decade the literacy rate of women increased 14 per cent as compared to male literacy rate. Females are still facing barriers for education e.g. lack of female teachers, school distance and inconvenience of transports. In rural areas, such problems are serious obstacles for girl's education.

Odomore (2015) identified that poverty, child marriage and traditional customs are barriers for girl's child education in developing countries. The parents are too poor they are unable to pay fees of a school and books, as a result, they dropout their girls. Thus mostly students not reach secondary level. The other factor is religious obstacles. People believe that women are a part of a home so they should not allow outside from home. The ratio of child marriage is very high in underdeveloped countries. Child marriage prevents girls from education. In the international level, many programs are carried out to solve this problem. Recent research shows that the attitude of the public is changing towards women.

Elias (2013) conducted research in Nigeria about issues challenges of female education. The researcher used multi-stage sampling techniques and data collected from 3993 respondents through the questionnaire. Validity and reliability were checked through Cronbach alpha coefficient. The findings show that gender discrimination, poverty, traditional values, the absence of sources and deficiency of government monitoring are the impediment for the female education.

Dhas and Sharmila (2010) identified that a significant change occurred in the field of education. The attitude of the community changed now they are sending their girls into schools. The rate of dropout is also decreased and the ratio of females in rural areas is also increased. Poverty is a push factor in education. Poor people are interested to send their girls into schools. People from rural areas are migrated to educate their children. Urbanization also attracts people to educate their girls into schools. They understand that education for the female is important as for boys. Government programs aware people about education and now people are giving more importance to a girl's education.

Saito et al (2014) discussed women inequity and low literacy rate. The theories claimed that societal norms and values shape the opinion of people about women education, politics and participation of women in institutional sectors. The dominant power of male and unequal distribution of resources from family to community kept women backwards and violate the basic rights of women in every field of life. The theory of change suggests some solution to solve women problems by providing resources like schools, colleges, transports and buildings. The new policies must be 
developed to remove discrimination against women in education, scholarships and politics. Social norms that are barriers for female education government should discourage those norms that violating women rights.

Thengal (2013) viewed that illiterate person faces hundred of difficulties in life e.g. health economic and political hurdles. Country progress depends upon the literacy rate of its public. The illiterate community is unable to participate in national development. Children of uneducated parents face a lot of problems like diseases, poverty and other social issues. The good structure of society depends upon the literate person of a community. They socialize their children in a better way. Parental education has a strong impact on child education the educated parents care about their child education. During infancy child face a lot of problems with their health skilled mother manage these problems without any barriers. An educated community of any country plays a good role in social and economic development.

Mohyuddin \& Ambreen (2012) viewed that parents in Pakistan discriminate against their daughters. They prefer their sons and consider that their sons are permanent family members. Their daughter will be married and earn for another family. Therefore, they always prefer and spend their income on their sons. As a result, their daughter remains illiterate. The data were collected from 100 households through simple random simple technique. The findings showed that child discriminate at the time of birth people become happy with sons and feel ashamed with the birth of daughters. This discrimination continues to whole life like in the field of education and property. The researcher found a change in the field of health now people take them into hospitals for treatment.

According to Women in Development approach women skipped from the process of development and man violate the status of women. This approach emphasizes that women must integrate with the process of development in this way women get equal rights in society. For national development, the participation of women is essential. The women and development approach criticize the global economic system and encourage class inequality. Women and development approach claimed that women are not for only reproduction but women play their role in the progress and production of the country. The Gender and Development approach discuss the impact of development both man and woman and it challenges the socially created roles that subordinate women (Muyoyeta).

Duffy argued that with the development of technology in this modern age women are still facing inequality and oppression of man. Men are dominant in all sectors of life and women have no benefits of development. Women are still behind in education, health, politics and employment sectors. The global approach sometimes lacks human rights this justice gains through the unity of men and women.

Mehra (1993) examined that in underdeveloped countries women are always busy in farming and earn for their family members. In rural areas, women are excluded from other sectors of life e.g. education and jobs. People in the rural areas are illiterate and they simply aware that women can only work in agriculture sectors. Due to illiteracy, women are unaware of their basic rights and they serve man as a slave. These oppressions paralyzed the lives of women.

\section{METHODOLOGY}

The present study was designed to explore the barriers that females are facing in the field of education. The target population of the study was Dera Ghazi Khan Tribal Area. The population here refers to the group of people the researcher used to get the results of the study (Leedy \& Ormrod, 2005). The study was conducted in the Tribal Area of District Dera Ghazi including Tammun Qaisrani and Tammun Leghari. The data was collected through simple random simple technique. The research is quantitative in nature so the questionnaire was used to collect data from the selected region. Likert Scale was used for research reliability and validity. Finally, the data was analyzed through Chi-square test.

\section{RESULTS AND DISCUSSIONS}

Table 01: Percentage distribution with regards to barriers to female education

\begin{tabular}{lll}
\hline Opinion & Frequency & Percentage \\
\hline
\end{tabular}

School distance 
Traditional barriers

Financial issues

Household work
$58.1 \%$

112

$70.0 \%$

103

The mentioned table illustrated the opinion of the people that are facing barriers for their children education. The majority of the people $73.7 \%$ respond that school distance is a serious issue for their girl's education. Traditional barriers are other hurdles for community many people feel ashamed to send their girls into school. 58.1\% feel that traditional customs are issues for them. Poverty is a massive issue for underdeveloped countries majority of people is unable to afford education. The main problems of Pakistan rural areas are financial issues where students cannot carry their education and parents dropout their children from schools. $70.0 \%$ responded that financial issues are stumbling block for children. Female children are not allowed for school as they have a lot of household work, as a result, their parent's drop out them from school. According to Sahoo (2016) the challenges that females are facing in the field of education like parental discrimination they prefer their sons for education and lack of female teachers in schools. Parents often feel ashamed to send their girls into male teachers. Lack of infrastructure like shelter less school, school distance, financial issues and problems of transports prevent girls from schools. Many students desire to carry their education for the middle and secondary level but the facilities of the hostel are not available for girls in schools. The household works are also obstacles for girl's education mostly girls are always with domestic work. The researcher found that parents are also disinterested to send their girls into schools they are unaware about the girl's education. Finally, the researcher suggested that to overcome such problems the government should take some initial steps for female education. Female education is essential for national economic and social development.

Table: 02 Percentage distributions regarding people opinion about female education

\begin{tabular}{|l|c|c|c|c|c|c|}
\hline Opinion & Agree & $\begin{array}{c}\text { Strongly } \\
\text { Agree }\end{array}$ & Uncertain & Disagree & $\begin{array}{l}\text { Strongly } \\
\text { Disagree }\end{array}$ & Percentage \\
\hline $\begin{array}{l}\text { School costs are barriers } \\
\text { for your girl's education }\end{array}$ & $63(39.3)$ & $49(30.6)$ & $11(6.9)$ & $28(17.6)$ & $9(5.6)$ & $160(100.0)$ \\
\hline $\begin{array}{l}\text { Male education is more } \\
\text { important than female } \\
\text { education }\end{array}$ & $52(32.6)$ & $39(24.3)$ & $11(6.9)$ & $41(25.6)$ & $17(10.6)$ & $160(100.0)$ \\
\hline $\begin{array}{l}\text { Higher income of a family } \\
\text { enroll their children } \\
\text { greater in a number other } \\
\text { than low income }\end{array}$ & $71(44.4)$ & $12(7.5)$ & $33(20.7)$ & $21(13.1)$ & $23(14.3)$ & $160(100.0)$ \\
\hline $\begin{array}{l}\text { Do you bear the expenses } \\
\text { of education for your girls }\end{array}$ & $43(26.8)$ & $17(10.6)$ & $7(4.4)$ & $35(21.9)$ & $58(36.3)$ & $160(100.0)$ \\
\hline $\begin{array}{l}\text { Female teachers are } \\
\text { significant for girls } \\
\text { education }\end{array}$ & $54(33.7)$ & $39(24.4)$ & $27(16.9)$ & $32(20.0)$ & $8(5.0)$ & $160(100.0)$ \\
\hline $\begin{array}{l}\text { Sons are more helping } \\
\text { hands than girls }\end{array}$ & $59(36.8)$ & $44(27.5)$ & $11(6.9)$ & $39(24.4)$ & $7(4.4)$ & $160(100.0)$ \\
\hline
\end{tabular}

Table No. 02 clearly depicts the attitude of the community about female education. The results showed that school costs, educational expenses are a barrier to female education. People also prefer their sons. This shows gender discrimination against female. Female teachers are also the preference of people. The public is also aware of the importance of female education that is support for family and society. Female education plays a crucial role in the progress of society. The government should hire female teachers in school as it play their role in a good way in society and it also ensures the parents to send their girls in school. Parents feel nervous from the male teachers. The public now aware to send their daughter for a better future but they are also facing barrier for 
education e.g. domestic task, child marriage and the traditional attitude of society. To make sure the public the attendance of teacher and transportation is necessary (Eram,2017)

\section{RECOMMENDATIONS}

The following recommendations are made on the basis of the study:

- Government should provide resources for people so that they should easily avail education.

- People are unable to bear expenses of higher education government must provide a scholarship for female students.

- Improve the condition of infrastructure in the tribal area.

- School distance is a serious issue for students so the provision of transport is compulsory.

- The allocation of special quota for the female in the government sector is compulsory.

- The provision of the job for the female so that people may increase their attention toward female education.

- Illiterate parents should be aware through awareness program and mass media.

\section{CONCLUSION}

The research shows that in underdeveloped countries women are facing trouble for education. Their lives are at risk. From family to community people discriminate against women. The dominant behavior of patriarchy system always supports their sons in every field of life. There is a literacy gap between boys and girls. This gap is a knell for girls as illiterate women are no more acceptable as a wife in society. Girls are facing problems for education e.g. school distance, expenses of education and cost of books. The low income is a problem for girls to achieve an education. The ratio of child marriage and domestic task are a factor for dropping out girls in school. It is concluded from the above discussion that females are still facing problems for education.

\section{REFERENCES}

Asano, S. (n.d). Gender Issues in Community Development. Alternative Movement against the Kobe City Artery Project, Post-Hanshin-Awaji Earthquake. Pp. 94-99.

Asghar, S. (1992). A study into Socio-economic Factors Associated with Female's Education in Rural areas of Faisalabad District. M.Sc. Thesis, Dept. of Rural Sociology, Univ. of Agri., Faisalabad, Pakistan.

Benz, A. (2012). The Crisis of School Education in Pakistan of Government's Failure and New Hopes in the Growing Private Education Sector; Internationales Asienforum,43(3-4),240-241.

Dhas,C. A. \& Sharmila, N. (2010). Development of Women Education in India. Online at http://mpra.ub.uni-muenchen.de/20680/ MPRA Paper No. 20680, posted 16. February 2010 00:35 UTC. Pp. 5-11.

Duffy,V. (n.d). Gender and Development.

Elias et al., (2013). Issues, Challenges and Prospects of Female Education in Nigeria:Implications for Sports Administration in Schools. Global Journals Inc. (USA), 13 (5), 9-15.

Eram U. (2017).Review Article on Attitude of Parents towards Girls Education; Saudi Journal of Medical and Pharmaceutical Sciences, DOI: 10.21276/sjmps, 3(6), 2413-4910 (Online)

Farrulsaqlain, M. (n.d). A Strategy to Eliminate Child Labour in Pakistan.

Ijaz et al. (2005). Effect of Socio-Economic Factors on the Female Education in Rural Areas of Faisalabad (Pakistan). Journal of Agriculture and Social Science Retrieved; http://www.ijabjass.org.

Ijaz, K. (1995). Sociology of Maternity and Child Health: some observations in the context of Pakistan. Department of Rural Sociology, University of Agriculture, Faisalabad-Pakistan.

Kaur, G \& Letic, J. (2012). Female Education and Economic Growth: theoretical overview and two country cases.

Khan, W, H. (2019). Barriers to Girls' Education.

Kola, Jacob. A. (2014). Effect of Socioeconomic and Sociocultural Barrier on Female Education: Implications for Students' Enrolment and Learning. 
Mehra, R. (1993). Gender in Community Development and Resource Management: An Overview. International Center for Research on Women 1717 Massachusetts Avenue N.W.

Washington, D.C. 20036. Pp. 3-9.

Mercy. (2017). An Assessment of Factors Militating Against Girl Child Education in Nigeria. International. Journal of Advanced and Multidisciplinary Social Science 2017, 3(2): 49-54

Mohyuddin, A \& Ambreen, M. (2013). Gender Biased Parental Attitudes towards Education: A Case Study of Village Dasuha, District Faisalabad. Academic Research International, 4 (1).140147

Muyoyeta, L (n.d). Women, Gender and Development. Publisher. Women for Change, Zambia and 80:20 Educating and Acting for a Better World, Ireland.

Odomore, A. (2015). Challenges to Female Education in the Developing World and International efforts to address those challenges.

Okorie, U, A. (2013). Women Education in Nigeria: Problems and Implications for Family Role and Stability. European Scientific Journal edition Vol. 9 (28), ISSN: 1857 - 7881.

Parveen, S. (2008). Female Education and National Development: As Viewed by Women Activists and Advocates: Bulletin of Education \& Research June 2008, 30(1),33-41

Patel, S. (2009). Tribal Education in India; A Case Study of Orisa. Mittal Publications.

Saeed, A., \& Abbasi, P. (2012). Critical Analysis of the Factors Influencing Female Education in Sindh as Viewed by Primary School Teachers; ijcrb.webs.com.2012 Institute of Interdisciplinary Business Research

Sahoo, S. (2016). Girls' Education in India: Status and Challenges. International Journal of Research in Economics and Social Sciences, 6(7), 130-141.

Saito, M et al. (2014). Girls' Education and Gender Equality. Education Rigorous Literature Review. Department for International Development.

Shantilin, S. (2011). Empowerment of Women through Education; A Case Study of Puducherry Union Territory. pp. 61-65

Shrivastava,S \& Jodan, A. (2018). Women Education in India: An Analysis. Research on Humanities and Social Sciences, 8(13);53-56. www.iiste.org

Shurgeel et al. (2015). A Review of Rural Women Education in Pakistan. Sci.Int. (Lahore), 27(1), 555-559.

Tembon, M \& Fort, L. (2008). Girls' Education in the 21st Century. Gender Equality, Empowerment, and Economic Growth. The International Bank for Reconstruction and Development / the World Bank.

Thengal,N (2013). Social and Economic Consequences of Illiteracy. International Journal of Behavioral Social and Movement Sciences, 02(02). 124-130.

UNICEF.(2008).Socio-Economic and Cultural Barriers to Schooling in Souter to their Education; International Journal of Advanced Engineering Technology hern Sudan.

Zahid, G. M, Saqib, N. U \& Arif, G.M. (1999). Poverty, Gender, and Primary School Enrolment in Pakistan. The Pakistan Development Review, 38(4), 979-992. 